\title{
Hypersensitivity Pneumonitis Caused by
Oyster Mushrooms: A Case of Mushroom Worker's Lung
}

\author{
İstiridye Mantarlarının Neden Olduğu Hipersensitivite Pnömonisi: Mantar İşçisi \\ Akciğeri Olgusu
}

Taha Tahir Bekçi', Mustafa Çalık², Burcu Yalçın'

\begin{abstract}
The commercial production of mushrooms is often carried out in indoor areas and controlled environments with intense labor performed throughout the year. Indoor cultivation can lead to allergic symptoms, such as extrinsic allergic alveolitis, also known as hypersensitivity pneumonitis, in workers. A 23-yearold male patient's symptoms emerged after beginning to work in mushroom cultivation. The patient was admitted to the clinic with complaints of chills, fever, joint pain, and a skin rash. Based on his medical history and a physical and radiographical examination, the patient was diagnosed as hypersensitivity pneumonitis and medical therapy was initiated. The patient's symptoms disappeared within a few days and he was discharged at the end of the first week. Given the difficulties in the diagnosis of disease, the patient's professional history should always be kept in mind as well as medical history, physical examination, and radiographic evaluation.
\end{abstract}

Key words: Oyster Mushroom, Pleurotus ostreatus, hypersensitivity pneumonitis, Mushroom worker's lung.

\section{Özet}

Mantar ticari üretimi yıl boyu kapalı iklimlendirilmiş ortamlarda emek yoğun şekilde yapılmaktadır. Kapalı ekim, işçilerde ekstrensek alleriik alveolitis olarak bilinen hipersensitivite pnömonisi gibi aleriik semptomlara yol açar. Yirmi üç yaşındaki erkek hastanın yakınmaları mantar üretim işine başladıktan sonra ortaya çıkmış. Hasta, üşüme, titreme, ateş, eklem ağrıları, cilt döküntüleri şikâyetiyle kliniğimize başvurdu. Hastanın anamnez, fizik muayene ve radyolojik incelenmesinde hipersensitivite pnömonisi düşünülerek medikal tedavi başlandı. Hastanın yakınmaları birkaç gün sonra geriledi. Birinci haftanın sonunda taburcu edildi. Hastalığın tanısında güçlüklerle karşılaşılsa da anamnez, fizik muayene ve radyolojik değerlendirmede akılda tutulmalıdır.

Anahtar Sözcükler: Istiridye mantarı, Pleurotus ostreatus, hipersensitivite pnömonisi, mantar işçisi akciğeri.
Edible mushrooms have been used as food and a medical substance to promote health and longevity for several centuries, especially in China and Japan (1). Today, a number of biologically active compounds, including polysaccharides, vitamins, terpenes, steroids, amino acids, and trace elements, have been identified in different mushroom species (1). Many edible mushrooms used in traditional folk medicine, including Lentinulaedodes (shiitake mushroom), Grifolafrondosa (maitake),

'Department of Chest Disease, Konya Education and Research

Hospital, Konya, Turkey

${ }^{2}$ Department of Thoracic Surgery, Konya Education and Research Hospital, Konya, Turkey

${ }^{1}$ Konya Eğitim Ve Araştırma Hastanesi, Göğüs Hastalıkları Kliniği, Konya

${ }^{2}$ Konya Eğitim Ve Araştırma Hastanesi, Göğüs Cerrahisi Kliniği, Konya

Submitted (Başvuru tarihi): 02.08.2017 Accepted (Kabul tarihi): 29.12.2017

Correspondence (iletişim): Burcu Yalçın, Department of Chest Disease, Konya Education and Research Hospital, Konya, Turkey

e-mail: burcu.samanyolu@yahoo.com 
Hericiumerinaceus, Flammulinavelutipes, Tremellamesenterica and Pleurotusostreatus are considered a good source of bioactive compounds (2). A cultivation technique of $P$. ostreatus on artificial substrate in airconditioned rooms rendered production economical throughout the year. The indoor cultivation, however, has regularly led to allergic symptoms in workers (3-6).

Hypersensitivity Pneumonia (HP) represents a heterogeneous group of diseases that are caused by repeated inhalation of organic antigens and inorganic lowmolecular-weight particles. These particles, which are usually 1 to $5 \mu \mathrm{m}$ in diameter, are deposited in distal air spaces and produce an immune-mediated inflammatory response in sensitized individuals. There is a wide spectrum of causative antigens, including fungi, bacteria, mammalian and avian proteins, small-molecular-weight chemical compounds, and wood dust (7).

\section{CASE}

The patient presented at the hospital with the complaints of chills, fever, joint paint, and a skin rash (Figure 1). On admission, his height was $178 \mathrm{~cm}$ and his weight was 73 $\mathrm{kg}$. His temperature was $38.2^{\circ} \mathrm{C}$, blood pressure was $110 / 70 \mathrm{mmHg}$, pulse rate was 96 beats per minute with a regular rhythm, and respiration rate was 18 per minute. Bilateral rough breathing sounds were audible in both lungs. Posteroanterior lung radiography showed bilateral, minimally ground-glass consolidation areas in both the upper and middle zones. Bilateral, ground-glass areas in the upper and middle zones of both lungs were also observed in a thoracic computed tomography (CT) scan (Figures 2 and 3). The patient was hospitalized with HP as a prediagnosis. The laboratory examination results were as follows: leukocytes, 14,000 K/u; C-reactive protein, $60.7 \mathrm{mg} / \mathrm{L}$; hemoglobin, $17.2 \mathrm{gr} / \mathrm{dL}$; hematocrit, 51\%; and immunoglobulin E level (lgE), $32.7 \mathrm{IU} / \mathrm{mL}$. Additional results were: sputum culture (-), acid-fast bacilli (-), nasal viral swab (-), and serum marker of collagen diseases (-). He had no history of previous medical disorders. There were no specific findings from flexible bronchoscopy or bronchoalveolar lavage (BAL). It was learned that the symptoms first started 3 months earlier after the patient began to work in mushroom production. Therapy of 40 mg methylprednisolone and an anti-histaminic was initiated and gradually reduced over the next 8 weeks. Follow-up did not indicate any deterioration of respiratory function. The patient's symptoms began to improve after a couple of days of medical treatment; the fever regressed, respiratory system complaints stopped, and the skin lesions improved. The lesions observed on the chest radiograph dissipated, and the patient was discharged after a week.

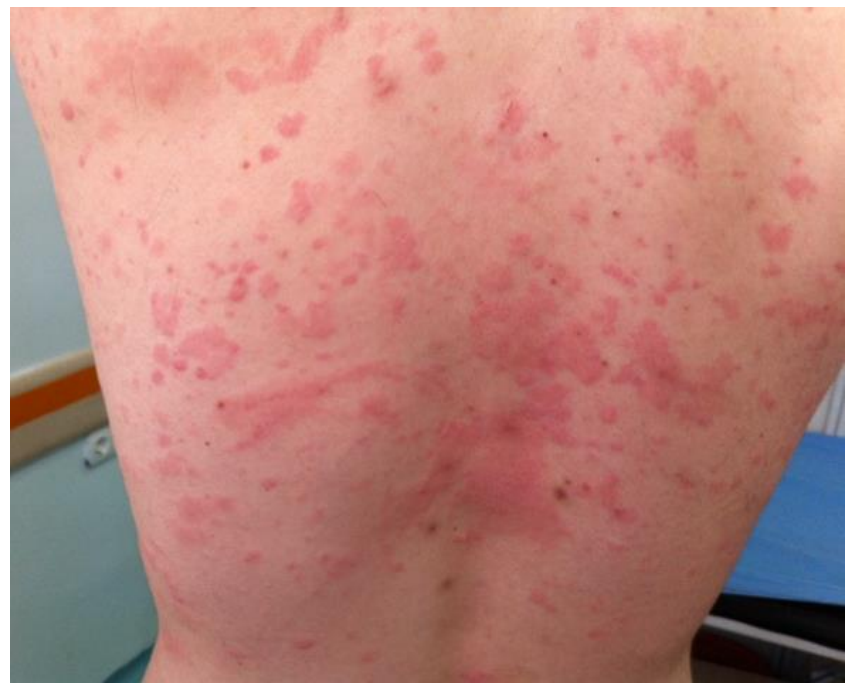

Figure 1: The patient's body rashes

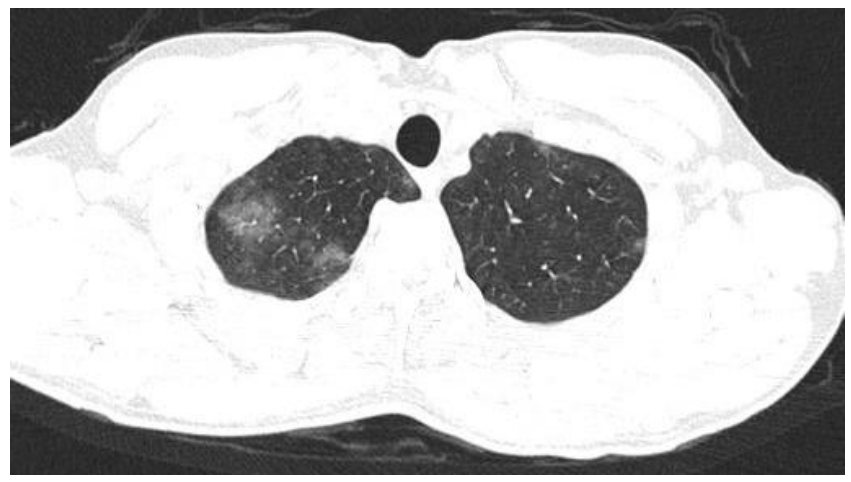

Figure 2: Thoracic CT scans of the patient

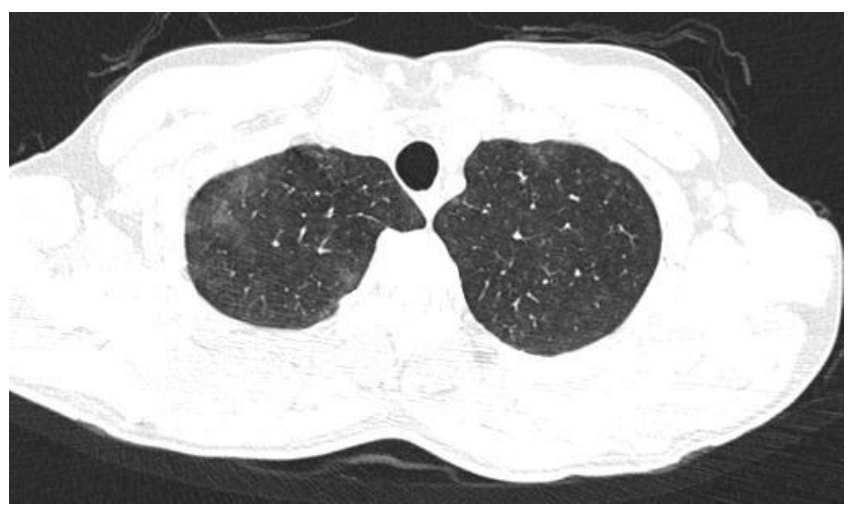

Figure 3: Thoracic CT scans of the patient

\section{DISCUSSION}

New sources of organic and inorganic antigens are continually being recognized. Work in a broad range of occupations increases the risk of developing HP (8). The first mushroom worker's lung (MWL) patient was reported 55 years ago $(9,10)$. The first, and a frequently seen type of 
$M W L$, is caused by the inhalation of a large number of thermophilicactinomycetes from compost used for the cultivation of Agaricusbisporus (9-11). There is different pathogenicity in $P$. ostreatus and A. bisporus (3). P. ostreatus discharges a tremendous amount of basidiospores in the course of cap growth before reaching a marketable size (11). The high incidence of MWL or respiratory symptoms may result from not only the high antigenicity but also the high concentration of basidiospores encountered in indoor cultivation of this fungus (12).

$\mathrm{HP}$ in susceptible people is a heterogeneous and uncommon non-lgE, T-helper cell type 1-mediated inflammatory pulmonary disease with systemic symptoms resulting from repeated inhalation of aerosolized antigenic organic dust and inorganic low-molecular-weight particles. More than 200 antigens can cause HP. The most common and well-studied forms are farmer's lung and bird fancier's lung (13).

HP caused by fungi may also occur in non-food industry employees such as farmers and those who work with cork, gypsum plaster or wood. Interestingly, despite exposure to a provoking antigen, only $5 \%$ to $15 \%$ of exposed individvals ever develop HP. Host risk factors are poorly characterized, with the exception of those linked to exposure. HP is more common in males than females, with an over representation of middle-aged individuals (14). Our case was a male worker at a mushroom farm. Although there is a diverse array of antigens that provoke HP, they share certain important characteristics. These characteristics include their size, solubility, particulate nature and their capacity to provoke a nonspecific inflammatory response and a specific immune reaction (15). HP may occur in acute, subacute, or chronic form, depending on the quantity and period of exposure (13). In the acute form, sensitive patients who were exposed to large amount of antigen experience shortness of breath, fever, chills, malaise, myalgia, and a non-productive cough after as little as just 4 to 8 hours. These symptoms disappear without any specific treatment within 24 hours once the triggering agent is removed. We observed similar findings in our case. The symptoms regressed after exposure to the antigen was eliminated. In the subacute/chronic phase, patients often present with slowly progressive shortness of breath, fatigue, low-grade fever, weight loss, and a chronic cough (13).

The clinical manifestations of HP are heterogeneous. All of the clinical forms of HP (i.e., acute, subacute, chronic), may mimic multiple diseases. There is no pathognomonic clinical, radiological, or laboratory examination, includ- ing lung biopsy, for the diagnosis. Therefore, all symptoms, BAL results, thoracic imaging techniques, laboratory tests, and usually a biopsy, have to be evaluated together (14). In practice, a transbronchial lung biopsy is often performed in patients with insufficient or suspicious clinical findings performed to distinguish from other interstitial lung diseases and make a definite diagnosis. High clinical suspicion and meticulous occupational and environmental histories are indispensable for accurate diagnosis (7). Diagnosis can be confirmed by clinical improvement observed with the elimination of the suspected antigen and induction of symptoms after antigenic stimulation. Most of the time, especially during the initial admission, there is no clear exposure history and symptoms are often nonspecific. The key to diagnosis is a high index of clinical suspicion in these patients (16). As in all lung diseases, radiography is often used as the initial workup. Typically chest $\mathrm{X}$-rays are normal or show minimal abnormalities. Then, high-resolution CT is performed (17). Although $\mathrm{CT}$ findings in patients with HP are often nonspecific, diagnosis can be confirmed without biopsy in patients with a characteristic appearance (18). The most common radiological findings in HP are ground-glass opacities and micronodules in the subacute form of the disease, and air-trapping in expiratory studies (19). Bilateral, ground-glass opacities were observed in our case.

Dermatological symptoms and skin disease can be seen with exposure to bioaerosols. We observed a skin rash in our case, which disappeared with medical treatment once the exposure was no longer present (20).

We were not able to analyze the serum precipitating antibodies against antigens to diagnose the patient because we cannot perform antigen tests in our hospital. It is a limitation of the case.

The obvious treatment in HP is the removal of the offending antigen. After removal of the antigen, progression of the disease stops. A patient with an acute attack usually recovers completely when exposure is prevented; however, if left untreated and with continued exposure to the trigger, permanent damage is possible. The only known, reliable pharmacological treatment for HP is the use of corticosteroids. In the long term, there is no benefit except in the event of a severe acute attack. In our case, improvement of the symptoms was observed once the agent was eliminated from his environment and steroid treatment was provided. 


\section{CONCLUSION}

The most important point in the treatment of HP is avoidance of antigen exposure. Employers should take some precautions to reduce the intensity and frequency of antigen exposure and employees need to be informed of the hazard.

\section{CONFLICTS OF INTEREST}

None declared.

\section{AUTHOR CONTRIBUTIONS}

Concept - T.T.B., B.Y., M.Ç.; Planning and Design T.T.B., M.Ç., B.Y.; Supervision - T.T.B., M.Ç., B.Y.; Funding - T.T.B., B.Y., M.Ç.; Materials - T.T.B., B.Y., M.Ç.; Data Collection and/or Processing - T.T.B., M.Ç., B.Y.; Analysis and/or Interpretation - T.T.B., M.Ç., B.Y.; Literature Review - T.T.B., M.Ç., B.Y.; Writing - T.T.B., M.Ç., B.Y.; Critical Review - T.T.B., M.Ç., B.Y.

\section{YAZAR KATKILARI}

Fikir - T.T.B., B.Y., M.Ç.; Tasarım ve Dizayn - T.T.B., M.Ç., B.Y.; Denetleme - T.T.B., M.Ç., B.Y.; Kaynaklar T.T.B., B.Y., M.Ç.; Malzemeler - T.T.B., B.Y., M.Ç.; Veri Toplama ve/veya İşleme - T.T.B., M.Ç., B.Y.; Analiz ve/veya Yorum - T.T.B., M.Ç., B.Y.; Literatür Taraması T.T.B., M.Ç., B.Y.; Yazıyı Yazan - T.T.B., M.Ç., B.Y.; Eleştirel Inceleme - T.T.B., M.Ç., B.Y.

\section{REFERENCES}

1. Mizuno T, Saito H, Nishitoba T, Kawagishi H. Antitumoractive substances from mushrooms. Food Rev Int 1995; 11:23-61. [CrossRef]

2. Sullivan R, Smith JE, Rowan NJ. Medicinal mushrooms and cancer therapy: translating a traditional practice into Western medicine. Perspect Biol Med 2006; 49:159-70. [CrossRef]

3. Cox A, Folgering HT, Van Griensven LJ. Extrinsic allergic alveolitis caused by spores of the oyster mushroom Pleurotus osteatus. Eur Respir J 1988; 1:466-8.

4. Michils A, De Vuyst P, Nolard N, Servais G, Duchateau J, Yernault JC. Occupational asthma to spores of Pleurotus cornucopiae. Eur Respir J 1991; 4:1143-7.

5. Van Loon PC, Cox AL, Wuisman OP, Burgers SL, Van Griensven LJ. Mushroomworker'slung. Detection of antibodies against Shii-take (Lentinusedodes) spore antigens in Shii-take workers. J Occup Med 1992; 34:1097-101.
6. Sastre J, Ibanez MD, Lopez M, Lehrer SB. Respiratory and immunological reactions among Shiitake (Lentinusedodes) mushroom workers. Clin Exp Allergy 1990; 20:13-19.

7. Unger GF, Scanlon GT, Fink JN, UngerJde B. A radiologic approach to hypersensitivity pneumonias. Radiol Clin North Am 1973; 11:339-56.

8. Mohr LC. Hypersensitivity pneumonitis. Curr Opin Pulm Med 2004; 10:401-11. [CrossRef]

9. Bringhurst LS, Byrne RN, Gershon-Cohen J. Respiratory disease of mushroom workers; farmer's lung. J Am Med Assoc 1959; 171;101-4.

10. Sakula A. Mushroom-worker's lung. Br Med J 1967; 3:708-10. [CrossRef]

11. Sanderson W, Kullman G, Sastre J, Olenchock S, O'Campo A, Musgrave K, et al. Outbreak of hypersensitivity pneumonitis among mushroom farm workers. Am J Ind Med 1992; 22:859-72. [CrossRef]

12. Mori S, Nakagawa-Yoshida K, Tsuchihashi H, Koreeda $Y$, Kawabata M, Nishiura $Y$, et al. Mushroom worker's lung resulting from indoor cultivation of Pleurotus osteatus. Occup Med 1998; 48:465-8. [CrossRef]

13. Küpeli. E, Karnak D. Hypersensitivity Pneumonitis. Tuberk Toraks 2011 ; 59:194-204. [CrossRef]

14. Selman M, Chapela R, Raghu G. Hypersensitivity pneumonitis: clinical manifestations, pathogenesis, diagnosis and therapeutic strategies. Sem Respir Med 1993; 14:353-64. [CrossRef]

15. Kaltreider HB, Caldwell JL, Adam E. The fate and consequence of an organic particulate antigen instilled into bronchoalveolar spaces of canine lungs. Am Rev Respir Dis 1977; 116:267-80.

16. Sharma OP. Hypersensitivity pneumonitis. Dis Mon 1991; 37:409-71. [CrossRef]

17. Gurney JW. Hypersensitivity pneumonitis. Radiol Clin North Am 1992; 30:1219-30.

18. Silver SF, Muller NL, Miller RR, Lefcoe MS. Hypersensitivity pneumonitis: evaluation with CT. Radiology 1989; 173:441-5. [CrossRef]

19. Glazer CS, Rose CS, Lynch DA. Clinical and radiologic manifestations of hypersensitivity pneumonitis. J Thorac Imaging 2002; 17:261-72. [CrossRef]

20. Lacasse Y, Selman M, Costabel U, Dalphin JC, Ando M, Morell $F$, et al. Clinical diagnosis of hypersensitivity pneumonitis. Am J Respir Crit Care Med 2003; 168:952-8. [CrossRef] 